\title{
SENGKETA PENGALIHAN SAHAM PERSEROAN TERBATAS YANG DISEPAKATI BERDASARKAN INVESTMENT AGREEMENT
}

(Studi Putusan Nomor 10/PDT.G/2010/PN.JKT PST jo. Putusan Nomor 629/

PDT/2011/PT.DKI.jo. Putusan Nomor 862 K/PDT/2013 jo. Putusan Nomor 238/PK/ $\mathrm{PDT} / 2014)$

\section{DISPUTE SHARES LIMITED COMPANY AGREED BASED ON INVESTMENT AGREEMENT}

\author{
Fatimah Rahmawati \\ Fakultas Hukum Universitas Brawijaya \\ Email : fatimaharahap01@gmail.com \\ Naskah diterima : 05/07/2018; direvisi : 27/07/2018; disetujui : 27/07/2018
}

\begin{abstract}
In term of business, limited company (PT) need an investor, therefore the investment agreement madeamong them, however dispute can also arise. One of the example is between PT. CTPI with PT. BKB in the case of shares transfer which has been agreed upon in the investment agreement.But in the dispute settlement there is a contradiction about the disputesubject particularly on the implementation of investment agreement with unlawful acts that have nothing to do with the investment agreement.Method used in this study is the normative legal research method, the case dismissed by the District Court on Decision Number 10 / PDT.G / 2010 / PN.JKT by stating that this dispute is not an implementation of the investment agreement and then strengthened to the level of review in the Supreme Court based on Decision Number 238PK / PDT / 2014 while in the appeal level of Judge decided that this is a dispute over the implementation of the investment agreement. Based on the review undertaken in this paper, an answer was obtained that the Judge at the District Court and the Supreme Court had ignored the binding power of the investment agreement and disrespected the agreement that had been made on the theory of justice as the basis for contracting.
\end{abstract}

\section{Keyword :Share transfer, limited company, Investment Agreement}

\begin{abstract}
Abstrak
Perseroan Terbatas dalam menjalankan usahanya membutuhkan investor maka dapat dibuat perjanjian investasi diantara mereka, namun dalam perjalanannya sengketa dapat juga timbul, salah satunya sengketa yang terjadi diantara PT. CTPI dengan PT. BKB dalam hal pengalihan saham PT. CTPI yang mana telah disepakati dalam investment agreement, akan tetapi dalam penyelesaian sengketa terdapat pertentangan mengenai pokok sengketa tentang pelaksanaan investment agreement dengan perbuatan melawan hukum yang tidak ada hubungannya dengan investment agreement, metode yang digunakan dalam kajian ini adalah metode penelitian hukum normatif, perkara ini telah diputus oleh Pengadilan Negeri berdasarkan Putusan Nomor 10/PDT.G/2010/PN.JKT dengan menyatakan bahwa sengketa ini bukan merupakan pelaksanaan investment agreement kemudian dikuatkan sampai tingkat peninjauan kembali di Mahkamah Agung berdasarkan Putusan Nomor 238PK/PDT/2014 sedangkan dalam tingkat banding Hakim memutuskan bahwa ini merupakan sengketa mengenai pelaksanaan investment agreement. Berdasarkan
\end{abstract}


kajian yang dilakukan dalam tulisan ini, diperoleh jawaban bahwa Hakim pada Pengadilan Negeri dan Mahkamah Agung telah mengabaikan kekuatan mengikat investment agreement dantidak menghormati perjanjian yang telah dibuat berdasarkan teori keadilan sebagai landasan dalam berkontrak.

\section{Kata kunci : Pengalihan Saham, PerseroanTerbatas, Investment Agreement}

\section{PENDAHULUAN}

Perseroan Terbatas ialah badan hukum yang terdiri dari persekutuan modal, didirikan berdasarkan pada perjanjian untuk menjalankan aktivitas usaha dengan modal dasar yang keseluruhannya terbagi dalam saham. ${ }^{1}$ Perseroan Terbatas dalam menjalankan aktivitas usahanya dibuat untuk mengejar keuntungan (profit oriented), namun iklim usaha tidak selalu baik.

Seiring perjalanannya Perseroan Terbatas dapat juga mengalami masalah keuangan, dalam mengatasi masalah ini Perseroan Terbatas dapat mencari investor dan melakukan perjanjian investasi (investment agreement) dimana perjanjian yang dilakukan antara investor (penanam modal) dengan suatu PT yang menjadi dasar hukum utama dan acuan bagi para pihak untuk melaksanakan kerjasama investasi.

Perjanjian investasi dalam hal ini sesuai dengan ketentuan yang diatur dalam Kitab Undang-Undang Hukum Perdata yang mengatur bahwa "semua perjanjian yang dibuat secara sah berlaku sebagai undangundang bagi mereka yang membuatnya".

Investasi atau penanaman modal yang dilakukan dalam PT dilakukan dengan:

a. Mengambil bagian saham pada saat pendirian Perseroan Terbatas;

b. Membeli saham; dan

c. Melakukan cara lain sesuai dengan ketentuan peraturan perundangundangan. ${ }^{3}$

${ }^{1}$ Abdulkadir Muhammad, Hukum Perusahaan Indonesia, PT Citra Aditya Bakti, Bandung, 2010, hlm. 109

${ }^{2}$ Pasal 1338 Kitab Undang-Undang Hukum Perdata

${ }^{3}$ Pasal 5 ayat (3) Undang-Undang Republik Indonesia Nomor 25 Tahun 2007 tentang Penanaman Modal, Lembaran Negara Republik Indonesia Tahun 2007 Nomor 67, Tambahan Lembaran Negara Republik Indonesia Nomor 4724
Pada dasarnya setiap kontrak (perjanjian) yang dibuat oleh para pihak harus dapat dilaksanakan dengan sukarela atau itikad baik, namun dalam kenyataannya kontrak yang dibuat sering kali diingkari atau dilanggar sehingga terjadi sengketa di antara para pihak. Sengketa merupakan situasi dimana terdapat pihak yang merasa dirugikan oleh pihak lain, yang mana kemudian pihak tersebut menyampaikan ketidakpuasan ini kepada pihak kedua (yang merugikannya). Jika situasi menunjukkan perbedaan pendapat, maka terjadilah apa yang dinamakan dengan sengketa. ${ }^{4}$

Hal ini juga dialami oleh PT. CIPTA TELEVISI PENDIDIKAN INDONESIA (selanjutnya disebut PT.CTPI) yang merupakan salah satu perusahaan stasiun televisi di Indonesia dan berdiri pada tahun 1990, pada tahun 2002 PT. CTPI membuat perjanjian investasi dengan PT. BERKAH KARYA BERSAMA (selanjutnya disebut PT . BKB), PT. BKB sebagai investor sepakat untuk memberikan bantuan modal sebesar US\$55,000,000.00 kepada PT.CTPI dengan kompensasi saham PT.CTPI sebesar $75 \%$, namun perjanjian ini tidak berjalan dengan baik timbul sengketa pada saat pengalihan saham $75 \%$ PT.CTPI kepada PT.BKB.

Awal mula sengketa dimulai ketika SHR melayangkan surat kepada PT BKB meminta kembali $75 \%$ saham TPI yang sudah dipindahtangankan dan SHR menjanjikan akan melakukan due dilligence (uji tuntas) untuk membayar kompensasi gantinya tanpa menjelaskan detil mekanisme pembayaran dan

4 Nurmaningsih Amriani, Mediasi: Alternatif Penyelesaian Sengketa Perdata di Pengadilan, , Raja Grafindo Persada, Jakarta, 2012, hlm..12 
sebagainya sehingga PT BKB pada 7 Maret 2005 menggelar rapat internal.

Rapat ini menghasilkan 3 opsi yang akan ditawarkan kepada SHR. Opsi pertama, PT BKB menjual $75 \%$ saham TPI yang dimilikinya kepada SHR seharga Rp 630 miliar. Opsi kedua, PT BKB membeli $25 \%$ saham TPI yang dimiliki SHR senilai Rp 210 miliar. Opsi ketiga, jika SHR tidak mengambil sikap maka kepemilikan saham di TPI tetap PT BKB sebesar $75 \%$ dan SHR $25 \%$.

Pada 8 Maret 2005 hasil rapat yang berisi 3 opsi tersebut kepada SHR dan pada 10 Maret 2005, PT BKB melayangkan surat pemanggilan RUPS kepada seluruh pemegang saham TPI untuk membahas opsi-opsi tersebut dalam rapat yang dijadwalkan pada 18 Maret 2005, SHR pun didaulat harus menyampaikan opsi yang dipilihnya paling lambat pada 17 Maret 2005, agar RUPS dapat membahas mengenai opsi yang dipilih SHR. Namun SHR tidak memberikan opsi yang diambil olehnya, ${ }^{5}$ SHR berpendapat melalui surat tanggal 16 Maret 2005 telah mencabut surat kuasa tanggal 3 Juni 2003 dan pada tanggal 17 maret 2018 SHR dan pemegang saham lainnya melakukan RUPSLB merombak jajaran direksi dan dewan komisaris TPI. RUPSLB ini dituangkan dalam Akta No. 114 di hadapan notaris Buntario Tigris Darmawa.

Pada tanggal 18 Maret 2005 PT BKB mengadakan RUPSLB memutuskan opsi ke 3, yakni kepemilikan tetap BKB $75 \%$ dan SHR 25\%. Pada tanggal 21 Maret 2005 keluar Surat Keputusan (SK) Menteri Hukum dan HAM No. C-07564. HT.01.04.TH.2005 tertanggal 21 Maret 2005 yang mengesahkan akta RUPSLB TPI yang dibuat pada tanggal 18 Maret 2005 sementara akta RUPSLB yang

${ }^{5}$ Detik Finance, Kronologi Sengketa Saham TPI, (Online), Juli 2010, https://finance.detik.com/bursa-dan-valas/d-1391619/kronologi-sengketa-saham-tpi, 2 April 2018

210 IUS Kajian Hukum dan Keadilan diselenggarakan SHR tanggal 17 Maret 2005 tidak pernah mendapat pengesahan dari Departemen Hukum dan Hak Asasi Manusia.

SHR dkk mengajukan gugatan ke PN dengan dasar telah dilakukannya $\mathrm{PMH}$ oleh PT BKB karena telah melakukan RUPSLB tanggal 18 Maret 2005 dan PT Sarana Rekatama Dinamika (PT SRD) sebagai perusahaan yang mengolah sisminbakum agar dibatalkan dan dinyatakan tidak sah keputusan RUPSLB tanggal 18 dan 19 Maret 2005 serta hasil keputusan RUPSLB tanggal 23 Desember 2005 dan memerintahkan para tergugat atau siapapun agar tidak mengambil tindakan apapun berdasarkan surat kuasa 3 Juni 2003, RUPSLB tanggal 18 Maret 2005.

Pengadilan Negeri Jakarta Pusat (selanjutnya disebut PN JAKPUS) mengabulkan gugatan Penggugat untuk sebagian, menyatakan Para Tergugat telah melakukan perbuatan melawan hukum. Majelis hakim juga memutuskan bahwa RUPSLB 17 Maret 2005 adalah sah dan sesuai dengan hukum, sedangkan RUPSLB 18 Maret 2005 tidak sah dan tidak berkekuatan hukum. ${ }^{6}$ Namun, putusan PN JAKPUS tersebut dibatalkan oleh pengadilan tingkat banding. Menurut majelis hakim banding, gugatan para penggugat tidak dapat diterima karena merupakan kewenangan BANI. ${ }^{7}$

Penggugat mengajukan permohonan kasasi atas putusan pengadilan banding tersebut. Mahkamah Agung mengabulkan permohonan Pemohon, dan membatalkan putusan Pengadilan Tinggi Jakarta. Menurut Majelis Kasasi, tindakan Termohon Kasasi melakukan pemblokiran RUPSLB 17 Maret 2005 dan meloloskan RUPSLB 18 Maret 2005, serta tindakan

\footnotetext{
${ }^{6}$ Putusan Pengadilan Negeri Jakarta Pusat Nomor: 10/Pdt.G/2010/PN Jkt Pst Tanggal 14 April 2011

${ }^{7}$ Putusan Pengadilan Tinggi Jakarta Pusat Nomor: 629/PDT/2011/PT DKI Tanggal 20 April 2012
} 
PT Berkah melaksanakan RUPSLB 18 Maret 2005, berada di luar perjanjian yang mengandung klausul arbitrase. ${ }^{8}$

Termohon kasasi mengajukan upaya hukum peninjauan kembali (PK) atas putusan tersebut. Menurut Pemohon PK, majelis hakim kasasi telah keliru dalam memberikan pertimbangan. Sebab, materi utama sengketa dalam perkara ini adalah tentang pelaksanaan RUPSLB PT. TPI tanggal 17 Maret 2005 dan RUPSLB tanggal 18 Maret 2005. Kedua RUPSLB tersebut bersumber dan terkait dengan investment agreement antara Pemohon PK dengan Termohon PK yang dengan tegas mengatur adanya klausul arbitrase.

Mahkamah Agung menolak permohonan peninjauan kembali pemohon. Menurut majelis PK, dalam perkara a quo adalah tentang perbuatan melawan hukum dan bukan merupakan sengketa mengenai hak berdasarkan Investment Agreement karena terdapat pihak yang tidak terikat dengan Investment Agreement terjadi antara Penggugat dengan Tergugat I dan Turut Tergugat I, sedangkan Tergugat II dan Turut Tergugat lainnya tidak terikat dengan isi perjanjian tersebut sehingga Pengadilan Negeri berwenang mengadili perkara $a$ quo Majelis PK juga berpendapat bahwa alasan pemohon peninjauan kembali lainnya merupakan pengulangan yang hanya mengenai perbedaan pendapat antara Pemohon PK dengan Judex Facti (Pengadilan Negeri) dan Judex Juris. ${ }^{9}$

Pertentangan pendapat terjadi dalam putusan pengadilan dimana pada tingkat pertama di PN Jakpus dan tingkat kasasi juga peninjauan kembali di Mahkamah Agung menyatakan ini merupakan $\mathrm{PMH}$ dan tidak ada hubungannya dengan Investment Agreement sedangkan Pengadilan Tinggi memutuskan ini bukan merupakan kewenangannya

\footnotetext{
8 Putusan Mahkamah Agung Republik Indonesia Nomor: 862 K/Pdt/2013 Tanggal 2 Oktober 2013

9 Putusan Mahkamah Agung Republik Indonesia Nomor: 238 PK/Pdt/2014 Tanggal 29 November 2014
}

karena penyelesaian sengketa ini adalah kewenangan BANI.

Penelitian ini menggunakan metode penelitian hukum normatif, yaitu mengkaji hukum sebagai norma, kaidah. Dari uraian latar belakang di atas penulis ingin menulis masalah mengenai mengapa kekuatan mengikat investment agreement dalam pengalihan saham PT Cipta Televisi Indonesia tidak didukung oleh Pengadilan Negeri dan Mahkamah Agung?.

\section{PEMBAHASAN}

Kesepakatan mengenai kompensasi saham ditegaskan dalam Butir B dari Preambule investment agreement tertanggal 23 Agustus 2002 yang berbunyi:

"The Existing Shareholders have agreed with the investor that the investor may acquire a majority shareholding in TPI conditional upon the investor subscribing for shares in PT. CTPI and arranging for the acqisition an restructuring of certain debts of PT. CTPI as more specifically described in this agreement" $" 10$

Artinya para pemegang saham setuju dengan investor bahwa investor akan mendapatkan saham-saham di PT.CTPI dan investor akan mengatur pengambilalihan beberapa hutang dari PT.CTPI seperti diuraikan dalam perjanjian. Dalam investment agreement tersebut disepakati bahwa PT. BKB setuju untuk menyediakan dana bagi PT.CTPI dengan jumlah US\$55,000,000.00 dengan perincian:

a. Sejumlah US\$25,000,000.00 untuk mengambil bagian saham mayoritas di TPI (hingga sebesar $75 \%$ dari seluruh modal saham yang ditempatkan dan disetor di PT. CTPI).

b. Sejumlah US\$30,000,000.00 untuk pembiayaan kembali/pengambilalihan dan retrkturisasi utang-utang PT. CTPI.

Kesepakatan para pihak tersebut tercantum dalam Pasal3.1. tentang share subscription yang berbunyi:

\footnotetext{
${ }^{10}$ Ibid, hlm. 26
} 
"subject to the terms of the share subscription agreement, the investor shall subscribe for and PT. CTPI shall issue to the Investor, shares in PT.CTPI constituting $75 \%$ (the "initial investor, shares in TPI constituting $75 \%$ (the initial investor stake") of PT. CTPI's total issued share capital, post subscription, on a fully diluted basis (the "Subscription Shares)"11 yang artinya dengan tunduk kepada share subscription agreement, investor (PT.BKB) akan mendapatkan saham yang akan diterbitkan oleh PT. CTPI sebesar $75 \%$ (bagian awal saham yang akan dimiliki oleh investor) dari total seluruh saham yang diterbitkan kemudian dengan dasar dilusi penuh saham-saham (saham yang dikeluarkan), sehingga menurut perjanjian ini PT.BKB berhak atas saham yang dikeluarkan.

Pada tanggal 3 Juni 2003 Para Pemegang Saham membuat dan menandatangani Surat Kuasa (power of attorney) sebagai pelaksanaan dari investment agreement tertanggal 23 Agustus 2002. Surat Kuasa tersebut diberikan kepada PT. BKB yang berisi:

a. Memanggil dan/atau menghadiri setiap dan segala RUPSLB PT. CTPI yang membahas antara lain:

1. Persetujuan atas perubahan susunan Direksi dan Komisars PT. CTPI, termasuk tetapi tidak terbatas pada menunjuk dan/atau mengakhiri anggota Direksi dan Komisaris dan memberikan $a c$ quit et de charge kepada Direksi dan Komisaris;

2. Persetujuan atas perubahan Anggaran Dasar PT. CTPI;

3. Persetujuan atas perubahan Anggaran Dasar PT. CTPI;

4. Hal-hal lain; b. Untuk membahas dan mengusulkan hal-hal yang terkait dengan agenda tersebutdiataspadaRUPSLBPT.CTPI dan membuat segala keputusan serta menggunakan hak suara dari sahamsahamnya seluruh Pemegang Saham pada PT. CTPI dalam RUPSLB;

c. Untuk mewakili, menghadiri serta bertindak untuk dan atas nama Pemegang Saham menghadap pihakpihak terkait, termasuuk Notaris dan Pemerintah Indonesia yang berwenang, untuk memberikan penjelasan dan untuk melaksanakan semua tindakan yang perlu sehubungan dengan maksud dan tujuan tersebut di atas;

d. Secara umum melakukan perbuatanperbuatan dan hal-hal yang tidak secaraspesifikdiberikansebagaikuasa dari Pemegang saham yang dianggap layak sehubungan dengan kuasa yang diberikan tersebut di atas; ${ }^{12}$

SuratKuasatersebutmenurutSiti Hardiyanti Rukmana telah dicabut melalui surat tanggal 16 Maret 2005 dan pada tanggal 17 Maret 2005 melakukan Rapat Umum Pemegang Saham Luar Biasa dan di hadiri seluruh pemegang saham PT. CTPI dan menghasilkan keputusan untuk merubah direksi, memberhentikan dengan hormat seluruh anggota direksi, dewan komisaris dan mengangkat direksi dan dewan komisaris baru.

Hasil keputusan RUPSLB ini tertuang dalam Akta Pernyataan Keputusan Rapat Pemegang Saham Nomor 114 Tanggal 17 maret 2005 dan dibuat di hadapan Notaris Buntario Trigis Darmawa Ng, S.H., S.E., M.H., Notaris di Jakarta dan telah dilaporkan kepada Kementrian Hukum dan Hak Asasi Manusia. Tetapi ketika pendaftaran dilakukan oleh Notaris Buntario Trigis

\footnotetext{
${ }^{12}$ Ibid, hlm. 30
} 
Darmawa Ng, S.H., S.E., M.H., secara online melalui Sistem Administrasi Badan Hukum (Sisminbakum) di bawah Instansi Kementerian Hukum dan Hak Asasi Manusia Republik Indonesia sistem tersebut tidak bekerja semestinya.

Pada tanggal 18 Maret 2005 diadakan Rapat Umum Pemegang Saham Luar Biasa PT. CTPI yang di hadiri PT. BKB atas diberikannya surat kuasa (power of attorney) oleh Ny.SitiHardiyantiRukmanadanpara pemegang saham PT.CTPI Tanggal 3 Juni 2003 kepada PT. BKB, dengan diberikannya surat kuasa tertanggal 3 Juni 2003 tersebut maka PT. BKB melakukan pengambilan keputusan dalamRapatUmumPemegangSaham Luar Biasa Pada tanggal 18 Maret 2005.

HasildariRapatUmumPemegang Saham Luar Biasa Pada Tanggal 18 maret 2005 adalah persetujuan tentang cara transaksi antara $\mathrm{Ny}$. Siti Hardiyanti Rukmana yang diwakili PT. Berkah Karya Bersama, persetujuan perubahan penggurus dan Perubahan Komposisi Pemegang Saham PT. CTPI serta telah sah mengubah hasil keputusan RUPSLB sebelumya. Kemudian hasil RU PSLB padatanggal18Maret2005dicatatkan pada Akta Pernyataan Keputusan Rapat Nomor 16 dan 17 tanggal 18 Maret 2005 yang keduanya dibuat di hadapan Bambang Wiweko S.H., M.H., Notaris di Jakarta dan berhasil didaftarkan di Kementerian Hukum dan Hak Asasi Manusia Republik Indonesia tanpa ada kendala.

RUPSLB kembali dilakukan PT. Berkah Karya Bersama pada Tanggal 19 Oktober 2005 dan dituangkan pada Akta Pernyataan Keputusan Rapat Nomor 128 pada Tanggal 19 Oktober 2005 yang dibuat di hadapan Sujipto S.H., Notaris di Jakarta dan pada Tanggal 19 Oktober 2005. KemudianRUPSLBPT.CiptaTelevisi Pendidikan Indonesia selanjutnya terjadi pada tanggal 23 Desember 2005.

\section{Pertimbangan Hakim}

Putusan pada tingkat kasasi dan peninjauan kembali dalam pokok perkaranya mengikuti pertimbangan Hakim pada tingkat pertama, pada pokok perkara Hakim PN menyoroti hal sebagai berikut:

1. Terdapat perbedaan pihak antara pihak yang membuat Perjanjian Investasi (investment agreement) dengan pihak yang terkait dengan gugatan ini yaitu PT. SRD (Tergugat II) sebagai Pengelola Sistem Administrasi Badan Hukum, dan Turut Tergugat I,II,III,IV,V,VI mengakibatkan hilangnya ketentuan arbitrase.

2. Pencabutan surat kuasa (Power of Attorney) tanggal 3 Juni 2003 yang digunakan oleh PT. BKB untuk melaksanakanRUPSLBtanggal18Maret 2005 adalah sah sehingga surat kuasa tersebut tidak berlaku lagi, pencabutan tersebut sah karena pemberian kuasa merupakan perbuatan sepihak yang dapat dicabut sewaktu-waktu.

3. Perkara ini bukan mengenai Perjanjian Investasi atau Investment Agreement karena gugatan yang diajukan merupakangugatan Perbuatan Melawan Hukum bukan gugatan Wanprestasi.

Pertimbangan Hakim Pengadilan Tinggi dalam tingkat banding mendukung Perjanjian Investasi (Investment Agreement) yang dibuat antara kedua Pihak, yang mana pertimbangan Hakim sebagai berikut:

1. Hakim dalam pertimbangannya menyatakan perkara ini merupakan sengketa mengenai pelaksanaan Perjanjian Investasi (Investment Agreement). Selanjutnya mengenai sengketa harus diselesaikan di 
Pengadilan Negeri atau Badan Arbitrase seharusnya mengikuti perjanjian yang telah dibuat yaitu Investment Agreement.

2. Pertimbangan Hakim menyatakan bahwa lembaga yang berwenang menyelesaikan perkara ini harus mengikuti ketentuan yang telah disepakati para pihak dinilai telah menghormatiklausularbitraseyangtelah disepakati dalam Perjanjian Investasi (InvestmentAgreement).MengenaiPihak Lain yang ikut digugat dalam sengketa ini Hakim mempertimbangkan bahwa kehadiran tersebut tidak menggugurkan kekuatan mengikat Investment Agreement

3. Hakim menimbang dalam kedudukan Menteri Hukum dan Hak Asasi Manusia sebagai Turut Tergugat masuk kedalam kewenangan Peradilan Tata Usaha Negara. Pertimbangan Hakim mengenai kekuatanmengikatinvestmentagreement apakah telah tepat.

\section{Hadirnya Pihak Ketiga Tidak Menggu- gurkan Perjanjian}

Dalam pertimbangannya Hakim melihat terdapat perbedaan pihak antara pihak yang membuat Perjanjian Investasi (investment agreement) dengan pihak yang terkait dengan gugatan ini yaitu PT. SRD (Tergugat II) sebagai Pengelola Sistem Administrasi Badan Hukum, dan Turut Tergugat I,II,III,IV,V,VI.

Menurut pertimbangan Hakim seperti yang dikutip di atas kehadiran Pihak yang tidak membuat Perjanjian Investasi (Investment Agreement) dalam gugatan ini maka hilang ketentuan Arbitrase. Hakim dalam hal ini menerapkan Pasal 1338 KUHPerdata yang mengatur bahwa:

"semua perjanjian yang dibuat sesuai dengan Undang-Undang berlaku sebagai Undang-Undang bagi mereka yang membuatnya. Persetujuan itu tidak dapat ditarik kembali selain dengan kesepakatan kedua belah Pihak, atau karena alasanalasan yang ditentukan oleh Undang-
Undang. Perjanjian harus dilaksanakan dengan itikad baik."

Pasal 1338 KUHPerdata mengenai kekuatan mengikat Perjanjian bagi Para Pihak yang membuatnya ini dikaitkan oleh Hakim kepada Pasal 4 Undang-Undang Nomor 30 Tahun 1999 tentang Arbitrase dan Alternatf Penyelesaian Sengketa, yang mengatur:

"Dalam hal para pihak telah menyetujui bahwa sengketa di antara mereka akan diselesaikan melalui arbitrase dan para pihak telah memberikan wewenang, maka arbiter berwenang menentukan dalam putusannya mengenai hak dan kewajiban para pihak jika hal ini tidak diatur dalam perjanjian mereka"

Menurut penafsiran Hakim terhadap Pasal ini bahwa perkara ini bukan perkara mengenai Perjanjian Investasi (Investment Agreement) karena kekuatan mengikat Perjanjian Investasi (Investment Agreement) hanya mengikat pada Pihak yang membuatnya saja yaitu Pemegang Saham PT. CTPI sebagai Penguggat dengan PT.BKB sebagai Tergugat I sehingga kehadiran pihak lain dalam perkara ini yaitu Tergugat II serta Turut Tergugat I,II,III,IV,V,VI menjadikan perkara ini bukan perkara mengenai (Perjanjian Investasi) Investment agreement.

Hakim telah keliru dalam menafsirkan Pasal 4 Undang-Undang Nomor 30 Tahun 1999 tentang Arbitrase dan Alternatf Penyelesaian Sengketa yang dikaitkan dengan kekuatan mengikat Perjanjian bagi Para Pihak yang ada di dalam Pasal 1338 KUHPerdata karena jika kita lihat dalam Pasal 5 ayat Undang-Undang Nomor 30 Tahun 1999 tentang Arbitrase dan Alternatif Penyelesaian Sengketa, yang mengatur bahwa:

(1) "Sengketa yang dapat diselesaikan melalui arbitrase hanya sengketa di bidang perdagangan dan mengenai hak yang menurut hukum peraturan 
Fatimah Rahmawati| Sengketa Pengalihan Saham Perseroan Terbatas Yang Disepakati Berdasarkan.

perundang-undangan dikuasai

sepenuhnyaoleh pihakyangbersengketa

(2) Sengketa yang tidak dapat diselesaikan melalui arbitrase adalah sengketa yang menurut peraturan perundangundangan tidak dapat diadakan perdamaian."

Seperti yang telah dijelaskan dalam pokok perkara bahwa permasalahan dalam perkara ini mengenai pengalihan saham PT.CTPI dalam RUPSLB tanggal 18 Maret 2005 yang mana sebagai pelaksanaan Perjanjian Investasi (Investment Agreement) yang mana terjadi kesepakatan PT. BKB sebagai Investor membayarkan sebagian utang PT.CTPI dengan kompensasi Pemegang Saham PT.CTPI memberikan 75 \% Saham PT.CTPI.

Pihak lain yang tidak ada dalam Perjanjian Investasi (Investment Agreement) yaitu PT.SRD yang dilibatkan dalam perkara ini hanya terkait pada pendaftaran dari hasil RUPSLB tanggal 17 Maret 2005 dan 18 Maret 2005 yang mana juga merupakan realisasi/pelaksanaan Perjanjian Investasi (Investment Agreement) begitu juga dengan dilibatkannya Pihak Turut Tergugat I, II, III, IV, V, VI dapat dianggap sebagai pelengkap dalam perkara ini.

Perjanjian arbitrase ditujukan kepada masalah penyelesaian perselisihan yang timbul dari perjanjian. Perjanjian ini bukan perjanjian "bersyarat". Pelaksanaan perjanjian arbitrase tidak digantungkan pada sesuatu kejadian tertentu. Perjanjian ini tidak mempersoalkan masalah pelaksanaan perjanjian, tetapi hanya mempersoalkan masalah cara dan pranata yang berwenang menyelesaikan perselisihan yang terjadi antara para pihak. ${ }^{13}$

\section{Perjanjian Pemberian Kuasa}

13 Susanti Adi Nugroho, Penyelesaian Sengketa Arbitrase dan Penerapan Hukumnya, : Prenadamedia Group, Jakarta, 2016, hlm. .101
Pertimbangan Hakim mengenai penarikan kuasa tersebut tidak tepat karena pemberian kuasa merupakan suatu perjanjian, hal ini dapat dilihat didalam Pasal 1792 KUHPerdata, yaitu:

"pemberian kuasa ialah suatu persetujuan dimana seseorang memberikan kekuasaan kepada orang lain yang menerimanya untuk atas namanya menyelenggarakan suatu urusan atau singkatnya suatu perjanjian dimana seseorang memberikan kekuasaan kepada orang lain dan orang itu menerima kekuasaan untuk melakukan sesuatu atas nama si pemberi perintah." 1415

Pemberian Kuasa merupakan persetujuan (overeenkomst) yang dapat disebut juga sebagai perjanjian karena dua pihak tersebut setuju untuk melakukan sesuatu. ${ }^{16}$ Perjanjian atau persetujuan merupakan perbuatan dimana satu orang atau lebih mengikatkan diri terhadap satu orang lain atau lebih. Dari peristiwa tersebut lahir suatu hubungan hukum antara dua orang/pihak atau lebih, yaitu yang dinamakan perikatan. Perjanjian atau persetujuan merupakan sumber penting yang melahirkan perikatan, dibandingkan dengan undang-undang sebagai sumber perikatan lainnya. ${ }^{17}$

\section{Surat Kuasa yang Tidak Dapat Ditarik Kembali}

Pemberian Kuasa yang merupakan perjanjian maka dalam penarikan Kuasa harus disetujui juga oleh pihak Penerima Kuasa, Surat kuasa mutlak dibuat dengan dampak yaitu pemberi kuasa tidak dapat mencabut kuasanya dari penerima kuasa. Biasanya sebuah surat kuasa akan dianggap sebagai surat kuasa mutlak dengan dicantumkan klausula bahwa pemberi kuasa akan mengenyampingkan atau

\footnotetext{
${ }^{14}$ Pasal 1792 Kitab Undang-Undang Hukum Perdata

${ }_{15}$ Putusan Pengadilan Negeri Jakarta Pusat Nomor: 10/Pdt.G/2010/PN.Jkt.Pst, op.cit hlm. 84

${ }^{16}$ Ketut Oka Setiawan, Hukum Perikatan, Sinar Grafika, Jakarta 2016, hlm.. 6

${ }^{17}$ Fajar Sugianto, Hukum Kontrak Teori dan Praktik Pembuatan Kontrak, Setara Press, Malang 2014, hlm.. 11
} 
mengabaikan Pasal 1813 KUHPerdata dan Pasal 1814 KUHPerdata yang mengatur mengenai berakhirnya pemberian kuasa.

Menurut kedua pasal tersebut, kuasa berakhir dengan penarikan kembali kuasa dari penerima kuasa, pemberitahuan penghentian kuasa oleh penerima kuasa, meninggal, pengampuan atau pailitnya pemberi kuasa maupun penerima kuasa, dan penarikan kembali kuasa oleh pemberi kuasa.

Dengan pencantuman klausula yang mengabaikan kedua pasal tersebut, maka pemberi kuasa menjadi tidak dapat untuk menarik kembali kuasanya tanpa kesepakatan pihak penerima kuasa. Dasar pemikiran yang mendukung pengabaian Pasal 1813 dan Pasal 1814 KUHPerdata adalah karena hukum perdata memiliki prinsip sebagai hukum pelengkap atau aanvullen recht. Selain itu tentu saja prinsip inti dari semua perjanjian, yaitu pact sunt servanda, asas konsensualisme, dan asas kebebasan berkontrak.

Surat kuasa ini dalam prakteknya sering disebut surat kuasa yang tidak dapat ditarik kembali atau disebut juga kuasa mutlak, kuasa mutlak ini dikenal dalam Yurisprudensi Mahkamah Agung antara lain pada:

a. "Putusan Mahkamah Agung tanggal 16

Desember 1976 Nomor 731 K/Sip/1975:

1. ketentuan Pasal 1813 KUHPerdata, tidak bersifat limitatif dan tidak mengikat, oleh karena itu jika sifat perjanjian memang menghendaki, dapat ditentukan pemberian kuasa yang tidak dapat dicabut kembali (kuasa mutlak)

2. Pasal 1813 KUHPerdata mengatur bahwa pemberian kuasa berakhir dengan penarikan kembali kuasa penerima kuasa; dengan pemberitahuan penghentian kuasanya oleh penerima kuasa, dengan meninggalnya, pengampuan atau pailitnya, baik pemberi kuasa maupun penerima kuasa dengan kawinnya perempuan yang memberikan atau menerima kuasa.

3. Pendirian ini didasarkan pada ajaran hukum adalah bersifat mengatur demikian juga mengenai meninggalnya pemberi kuasa dikaitkan dengan surat kuasa mutlak, telah diterima penerapannya di Indonesia sebagai kebutuhan, sehingga tidak bertentangan dengan Pasal 1339 dan 1347 KUHPdt.

4. Putusan Mahkamah Agung tanggal 17 November 1987 Nomor 3604 K/ Pdt/1985menegaskankembalinorma yang terdapat dalam Putsusan di atas: surat kuasa mutlak tidak dijumpai aturannya di dalam Kitab UndangUndang Hukum Perdata namun demikian Putusan Mahkamah Agung mengakui keberadaannya sebagai suatu kebutuhan hukum"18

Kekeliruan Hakim dalam pertimbangannya yaitu membenarkan pencabutan surat kuasa oleh pihak penggugat mengakibatkan pertimbangan Hakim selanjutnya dalam menilai keabsahan RUPSLB tanggal 18 Maret2005, Hakim berpendapat penyelenggaraan RUPSLB oleh PT. BKB adalah perbuatan melawan hukum karena didasari oleh surat kuasa yang telah dicabut tersebut.

\section{Perbuatan Melawan Hukum Dan Wan- prestasi}

Dalam pertimbangannya Hakim juga berpendapat bahwa perkara ini bukan mengenai Perjanjian Investasi atau Investment Agreement karena gugatan yang diajukan merupakan gugatan Perbuatan Melawan Hukum bukan gugatan Wanprestasi.

Wanprestasi (default atau non fulfiment ataupun yang disebut juga dengan istilah breach of contract) adalah tidak dilaksanakan prestasi atau kewajiban sebagaimana mestinya yang dibebankan

${ }^{18}$ Panggabean, Analisis Yurisprudensi Hukum Bisnis, Alumni, Bandung, 2014, hlm. 305 
oleh kontrak terhadap pihak-pihak tertentu seperti yang disebutkan dalam kontrak yang bersangkutan, seseorang dikatakan wanprestasi apabila ia melanggar suatu perjanjian yang telah disepakati dengan pihak lain tiada wanprestasi apabila tidak ada perjanjian sebelumnya.

Dalam Pasal 1365 Kitab UndangUndang Hukum Perdata menentukan bahwa tiap perbuatan melawan hukum yang mengakibatkan kerugian pada orang lain, mewajibkan orang yang melakukan perbuatan tersebut untuk mengganti kerugian. Sehingga seseorang dikatakan melakukan perbuatan melawan hukum apabila perbuatannya bertentangan dengan hak orang lain, atau bertentangan dengan kewajiban hukumnya sendiri, atau bertentangan dengan kesusilaan.

Setiawan, mantan Hakim tinggi yang sekarang menjadi Hakim Arbiter BANI berpendapatbahwa perbedaan wanprestasi dan perbuatan melawan hukum yang dijadikan perdebatan sebenarnya tidak lebih dari upaya salah satu pihak untuk menghindar memenuhi kewajibannya. ${ }^{19}$

\section{Pertimbangan Hakim Ditinjau Den- gan Teori Keadilan Sebagai Landasan Dalam Hubungan Kontraktual}

Pertimbangan Hakim yang tidak mendukung kekuatan mengikat Perjanjian Investasi (Investment Agreement) di antara Para Pihak tentunya bertentangan dengan teori keadilan dalam berkontrak yang mana teori keadilan sebagai landasan dalam hubungan kontraktual (Upianus) menyatakan keadilan sebagai "justitia est constans et perpetua voluntas ius suum cuiqe tribuendi" (keadilan merupakan kehendak yang terus-menerus dan tetap memberikan kepada masing-masing apa yang menjadi haknya) atau "tribuere cuiqe suum" (memberikan setiap orang yang

\footnotetext{
19 Setiawan, Perbuatan Melawan Hukum dan Wanprestasi sebagai Dasar Gugatan, (online), 2012, http://www.hukumonline.com/berita/baca/hol3616/ perbuatan-melawan-hukum-dan-wanprestasi-sebagai-dasar-gugatan, (25 April 2018)
}

menjadi haknya) perumusan ini secara tegas mengakui hak masing-masing pihak yang seharusnya menjadi bagiannya dan kewajiban untuk memenuhinya.

Perjanjian Investasi (Investment Agreement) merupakan perjanjian yang telah dibuat antara PT. BKB dengan Pemegang Saham PT. CTPI, seperti yang telah disebutkan sebelumnya bahwa ditegaskan dalam perjanjian tersebut hak dan kewajiban masingmasing pihak apabila terjadi kegagalan dalam pelaksanaan kontrak, maka kadar kesalahan harus diukur berdasarkan asas proporsionalitas, sehingga terhadap kesalahaan kecil (minor important) tidak serta merta mengakibatkan pemutusan kontrak atau pembebanan ganti rugi terhadap pihak lain. Hal demikian adalah tidak proporsional dan karenanya harus ditolak berdasarkan asas proporsionalitas.

\section{SIMPULAN}

Pertimbangan Hakim Pengadilan Negeri dan Mahkamah Agung yang tidak mendukung kekuatan mengikat Perjanjian Arbitrase (Investment Agreement) adalah terdapat Pihak lain (Tergugat II dan Turut Tergugat II, III, IV, V, VI, VII) di luar Pihak yang membuat Perjanjian, surat kuasa tanggal 3 Juni 2003 yang digunakan PT.BKB dalam menyelenggarakan RUPSLB tanggal 18 Maret 2005 telah dicabut dan gugatan yang diajukan penggugat merupakan gugatan perbuatan melawan hukum bukan merupakan gugatan wanprestasi sehingga permasalahan ini bukan merupakan sengketa perjanjian investasi (investment agreement), pertimbangan tersebut dinilai tidak menghormati Perjanjian yang telah dibuat berdasarkan teori keadilan sebagai landasan dalam berkontrak.

\section{DAFTAR PUSTAKA}

\section{Buku}

Abdulkadir Muhammad, 2010, Hukum Perusahaan Indonesia, PT Citra 
Aditya Bakti, Bandung.

Fajar Sugianto, 2014, Hukum Kontrak

Teori dan Praktik Pembuatan

Kontrak, Setara Press, Malang.

Ketut Oka Setiawan, 2016, Hukum

Perikatan, Sinar Grafika, Jakarta,

M. Yahya Harahap, 2008, Arbitrase, Sinar Grafika, Jakarta.

Nurmaningsih Amriani, 2012, Mediasi: Alternatif Penyelesaian Sengketa Perdata di Pengadilan, Raja Grafindo Persada, Jakarta.

Susanti Adi Nugroho, 2016, Penyelesaian Sengketa Arbitrase dan Penerapan Hukumnya, Prenadamedia Group, Jakarta.

Wawan Muhwan, 2011, Hukum Perikatan dilengkapi Hukum Perikatan Dalam Islam, Pustaka Setia, Bandung,

\section{Peraturan Perundang-Undangan}

Kitab Undang-Undang Hukum Perdata

Undang-Undang Republik Indonesia Nomor 25 Tahun 2007 tentang Penanaman Modal, Lembaran Negara Republik Indonesia Tahun 2007 Nomor 67, Tambahan Lembaran Negara Republik Indonesia Nomor 4724 